\title{
Characterization by PCR-RFLP of the Cryptococcus neoformans and Cryptococcus gattii species complex in Venezuela
}

Giuseppe Ferrara ${ }^{1}$, María Mercedes Panizo ${ }^{1}$, Emilia Urdaneta ${ }^{1}$, Victor Alarcón ${ }^{1}$, Nataly García ${ }^{1}$, Xiomara Morenón, Ana María Capote ${ }^{l}$, Vera Reviakina ${ }^{l}$ and Maribel Dolande ${ }^{l}$.

${ }^{1}$ Departamento de Micología, Instituto Nacional de Higiene Rafael Rangel. Caracas, Venezuela

${ }^{2}$ Instituto Médico La Floresta. Caracas, Venezuela.

Keywords: Cryptococcosis; $C$. neoformans and C. gattii species complex; PCR-RFLP; URA5; genotypes.

\begin{abstract}
Cryptococcosis is a sub-acute or chronic mycosis caused by opportunistic yeasts of the Cryptococcus genus, mainly by the $C$. neoformans and C.gattii species complex. This disease tends to position itself as one of the first opportunistic conditions associated with AIDS, with a high morbidity in these patients, who frequently develop meningoencephalitis. To date, there are techniques that allow the identification of the eight molecular types associated with these species complex, but there is little information about their circulation in Venezuela. The purpose of this work was to perform the molecular characterization of the $C$. neoformans and C.gattii species complex by PCR-RFLP. A total of 80 strains were used, 65 of the $C$. neoformans complex (CNC) and 15 of the $C$. gattii complex (CGC), following the protocol described by Escandon et al., carrying out the amplification of the URA5 gene and subsequent digestion with the Sau96I and HhaI restriction enzymes, that generated band patterns that allowed the identification of different molecular types. The most prevalent molecular type was VNI with $68.75 \%(n=55)$, similar to that reported worldwide;secondly, VGII molecular type with con $15 \%(n=12)$, which corresponds to that reported for Latin America, followed by VNII with $11.25 \%(\mathrm{n}=9)$, VGIII with $2.5 \%(\mathrm{n}=2)$, VNIII with $1.25 \%(\mathrm{n}=1)$ and VGI with $1.25 \%$ $(n=1))$. Ninety-two point three percent of CCN $(n=60)$ and $66.7 \%(n=10)$ of GCC isolates were from patients with HIV/AIDS. This study provided important epidemiological information on circulating molecular types and allowed to deepen the knowledge of this opportunistic mycosis in Venezuela.
\end{abstract}




\section{Caracterización de los complejos de especies Cryptococcus neoformans y Cryptococcus gattii mediante PCR-RFLP en Venezuela}

Invest Clin 2018; 59(1): $28-40$

Palabras clave: Criptococosis; complejo de especies $C$. neoformans y $C$. gattii; PCR-RFLP; URA5; genotipos.

Resumen. La criptococosis es una micosis de curso subagudo o crónico causada por levaduras oportunistas del género Cryptococcus, principalmente por los complejos de especies $C$. neoformans y $C$. gattii. Esta enfermedad tiende a posicionarse como una de las primeras afecciones oportunistas asociadas al SIDA, con una elevada morbilidad en estos pacientes, quienes con frecuencia desarrollan meningoencefalitis. En la actualidad, existen técnicas que permiten la identificación de los 8 tipos moleculares asociados a estos complejos de especies, sobre los cuales existe escasa información sobre su circulación en Venezuela. El propósito de este trabajo fue realizar la caracterización molecular de los complejos de especies $C$. neoformans y $C$. gattii por PCR-RFLP.Se utilizaron 80 cepas, 65 del complejo $C$. neoformans (CCN) y 15 del complejo $C$. gattii (CCG), siguiendo el protocolo descrito por Escandón y col.,se realizó la amplificación del gen URA5 y posterior digestión con las enzimas de restricción Sau96I and HhaI, que generaron patrones de bandas que permitieron identificar los diferentes tipos moleculares. El tipo molecular más prevalente fue el VNI con $68,75 \%(n=55)$, similar a lo reportado a nivel mundial; en segundo lugar, el tipo molecular VGII con $15 \%(n=12)$, que concuerda con lo reportado para Latinoamérica, seguido de VNII con 11,25\% ( $\mathrm{n}=9)$, VGIII con $2,5 \%(n=2)$, VNIII con $1,25 \%(n=1)$ y VGI con $1,25 \%(n=1)$. El $92,3 \%$ de los aislados del CCN $(n=60)$ y el 66,7 \% $(n=10)$ de los CCG provenían de pacientes con VIH/SIDA. Este estudio aportó información epidemiológica importante sobre los tipos moleculares circulantes y permitió profundizar en el conocimiento de esta micosis oportunista en Venezuela.

Recibido: 05-10-2017 Aceptado: 08-03-2018

\section{INTRODUCTION}

Cryptococcosis is a sub-acute or chronic mycosis caused by opportunistic yeasts of the Cryptococcus genus, mainly by the $C$. neoformans and $C$. gattii species complex. This condition begins with inhalation of yeasts and/or basiodiospores reaching the pulmonary alveoli of the host, and in the absence of an effective immune response, are disseminated hematogenously to other organs and systems, mainly to the Central Nervous System (CNS) $(1,2)$.These complexes differ in their ecological, epidemiological and virulence characteristics (2-6).

Limitations of conventional diagnosis, and the increase in the incidence of cryptococcosis,

Vol. 59(1): 28 - 40, 2018 
have led to the development of molecular typing tools for the characterization of pathogenic species of the Cryptococcus genus from clinical and environmental isolates, among which the following stand out: PCR fingerprinting (PCR-FP), Restricted Fragment Length Polymorphism (RFLP) and Multilocus Sequence Typing(MLST)(7-11).

At present, molecular techniques such as PCR-RFLP and PCR-FP allow the identification of eight molecular types, associated with these species complex: VNI and VNII corresponding to $C$. neoformans var. grubii (serotypeA), VNIII corresponds to hybrid AD and VNIV corresponds to $C$. neoformans var.neoformans (serotypeD); the VGI, VGII, VGIII, and VGIV types to Cryptococcus gattii (serotypesB andC) $(3,5-7,9,12)$.

The data obtained in the epidemiological studies using these techniques have revealed that in the case of the Cryptococcus genus, genotypic adaptation has brought with it great phenotypic changes, and the subsequent alteration of its virulence factors. Cases of relapse and treatment resistance have also been described, demonstrating that epidemiological studies on cryptococcosis are essential for understanding the biology of this fungus, allowing the improvement of current therapy against this infection $(8,13-15)$.

There are few epidemiological studies and of information on the incidence and prevalence of cryptococcosis in Venezuela (11,15-19). With this work, the characterization of the Cryptococcus neoformans and Cryptococcus species complex circulating in Venezuela, was established, using the PCR-RFLP technique.

\section{MATERIALS AND METHODS}

An experimental, analytical and descriptive study was carried out to characterize molecularly the strains of $C$. neoformans/ $C$. gattii species complex, with an intentional and non-probabilistic selection sampling. The study was approved by the bioethic committees of the "Francisco de Miranda" National Experimental University and the "Dr. Jose Gregorio Hernandez" Western General Hospital.

\section{Origin of the isolates}

Eighty strains of $C$. neoformans/C. gattii species complex were characterized,coming from biological material of hospitalized patients of public and private hospitals, located in different regions of Venezuela, diagnosed with cryptococcosis during the period 2004-2010. These samples were sent to the Mycology Department of the "Rafael Rangel" National Institute of Hygiene (RRNIH), which serves as a national reference center for infectious diseases. The strains were identified at genus and species level by conventional tests such as carbohydrate assimilation by the Huppert method modified by Moore, ID 32C $($ (BioMérieux, France) and urea hydrolysis $(20,21)$, and preserved by Castellani method in the RRNIH Fungi Collection(22). Information on demographic data (gender, age), geographic region, anatomical site of isolation and patient's base disease was compiled in a database

\section{Preparation of isolates}

The recovery of isolates deposited in the fungi collection was carried out by cultivating them for 48 hours at $28^{\circ} \mathrm{C}$ on Sabouraud dextrose agar, verifying its viability and purity. The taxonomic identification of the strains was again performed using the phenotypic tests mentioned above plus the use of the B-glycinecanavanine-blue bromothymol selective agar for the differentiation of species complex $(20,21,23)$. 


\section{DNA extraction}

For each of the isolates, a suspension in one McFarland sterile saline solution was performed in a densitometer (Densimat TM BioMérieux) at $530 \mathrm{~nm}$. One $\mathrm{ml}$ was dispensed in Erlenmeyer flasks with $25 \mathrm{~mL}$ of YPD liquid medium (Dextrose, peptone and malt extract, Oxoid), incubated for $48 \mathrm{~h}$ at $120 \mathrm{rpm}$ on an orbital shaker at $28^{\circ} \mathrm{C}$. This suspension was then adjusted to four McFarland, and the QIAamp DNA Mini kit (Qiagen, Germany) was used, using tissue protocol, which included prior enzymatic digestion with lyticase and spheroplasts obtaining, all according to manufacturer's instructions. The products were stored at $-20^{\circ} \mathrm{C}$.

\section{Molecular characterization of the Cryptococcus complex}

Amplification of the URA5 gene was performed followed by restriction analysis with Sau96I and HhaI enzymes, using the protocol described by Escandon et al. (3), with modifications. Five $\mu$ L of the extracted DNA was placed in a reaction mixture prepared with $10 \mathrm{mM}$ Tris- $\mathrm{HCl}$ buffer solution ( $\mathrm{pH} 8.8$ ), $10 \mathrm{mM} \mathrm{KCL}$, $0.002 \%$ Tween $20 \mathrm{vol} / \mathrm{vol}$ (Invitrogen, USA);50

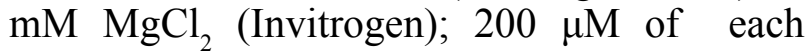
dNTP (Invitrogen, USA); $0.1 \mathrm{mM}$ dithiothreitol (Invitrogen, USA); $40 \mathrm{U} / \mu \mathrm{L}$ recombinant ribonuclease inhibitor (Invitrogen, USA); 10 $\mathrm{mM}$ of each primer (Bioneer,USA) URA5(5'ATGTCCTCCCAAGCCCTCGACTCCG-3') and SJ01(5' -TTAAGACCTCTGAACACCGTACTC-3'); $5 \mathrm{U} / \mu \mathrm{L}$ Recombinant Taq polymerase (Invitrogen, USA), and nuclease water free (Invitrogen, USA) to thereby complete a volume of $50 \mu \mathrm{L}$ per reaction.

Amplification was performed on a Perkin Elmer 2400 thermocycler under the following conditions:initial denaturation at $94^{\circ} \mathrm{C}$ for 3 minutes; 35 cycles of: denaturation at $94^{\circ} \mathrm{C}$ for 45 seconds, annealing at $62^{\circ} \mathrm{C}$ for 1 minute, extension at $72^{\circ} \mathrm{C}$ for 2 minutes, and final extension at $72^{\circ} \mathrm{C}$ for 10 minutes. The products were analyzed by electrophoresis on $2 \%$ agarose gel at $120 \mathrm{~V}$ for one hour, and visualized in a gel documentation system (Gel Doc XR $\AA$, Bio-Rad, USA). The presence of a band of $779 \mathrm{bp}$ was considered positive for the product generated in the PCR (Fig. 1).

For RFLP, the URA5 gene amplified product was subjected to double enzymatic digestion using the Sau96I (5000 U/mL) and HhaI (20000 $\mathrm{U} / \mathrm{mL}$ ) enzymes (New England BioLabs, USA) incubated at $37^{\circ} \mathrm{C}$ in dry for 3 hours. The products were analyzed by electrophoresis in 3\% agarose gel at $100 \mathrm{~V}$ for one hour, and visualized in the gel documentation system (Doc XR ${ }^{\circledR}$ Gel, BioRad, USA).

Restriction patterns were visually assigned to molecular types (VNI to VNIV and VGI to VGIV) by comparing them to patterns obtained from the reference strains: WM 148 (VNI); WM 626 (VNII); WM 628 (VNIII); WM 629 (VNIV); WM 179 (VGI); WM 178 (VGII); WM 161 (VGIII); and WM 779 (VGIV) (Fig. 1) $(3,12)$. These strains were kindly provided by the Colombia National Institute of Health.

In the PCR amplifications, positive and negative controls to appropriate validation of the results and 50 and $100 \mathrm{bp}$ markers were included. An internal control of reaction was used to determine the presence of PCR inhibitors.

\section{Isolates}

\section{RESULTS}

Sixty five strains were identified as $\mathrm{CNC}$ and 15 as CGC complex, corresponding to $81.25 \%$ and $18.75 \%$, respectively, of which $92.3 \%$ of $\mathrm{CNC}(\mathrm{n}=60)$ and $66.7 \%(\mathrm{n}=10)$ of the CGC came from patients with HIV/AIDS.

Gender distribution showed a predominance of male gender with $80 \%(n=64)$. The ages for men ranged from 18 to 71 years, with an average

Vol. 59(1): 28 - 40, 2018 


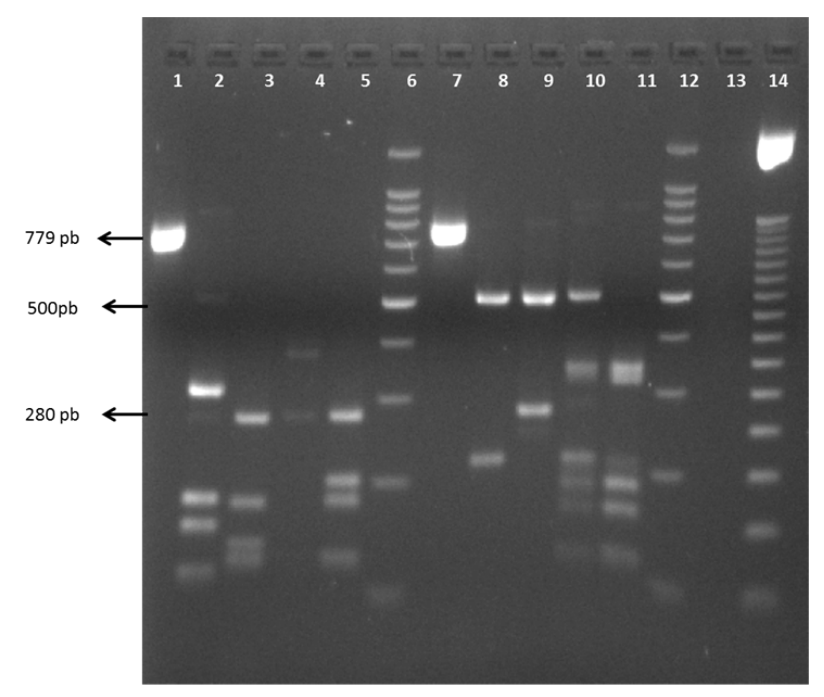

Fig. 1. PCR products of the URA5 gene and PCR-RFLP profile by double digestion with Sau96I and HhaI enzymes of the references strains. Columns 1 and 7: PCR products of the $C$. neoformans (WM 148-VNI) y C. gattii (WM 178-VGII) URA5 gene, respectively; Column 2: VGI molecular type; Column 3: VGII molecular type; Column 4: VGIII molecular type; Column 5: VGIV molecular type; Column 8: VNI molecular type; Column 9: VNII molecular type; Column 10: VNIII molecular type; Column 11: VNIV molecular type; Columns 6 and 12: 100 bpmolecular marker; Column 13: empty; Column 14: 50 bpmolecular marker.

of $38.7 \pm 9.9$; for women it ranged from 19 to 66 years, with an average of $39.5 \pm 10.2$. The isolates distribution according to base disease of patients is shown in Table I.

The predominant clinical form in patients with CNC isolates was meningoencephalitis with $93.8 \% \quad(n=61)$, followed by fungemia and pulmonary cryptococcosis, with $4.6 \%$ $(\mathrm{n}=3)$ and $1.6 \% \quad(\mathrm{n}=1)$, respectively. In patients with $\mathrm{CGC}$ isolates, the clinical form was meningoencephalitis $(100 \%)$. The geographic origin of isolates from patients with cryptococcosis is shown in Fig. 2.

\section{URA5 gene amplification by PCR}

The URA5 gene was amplified from the under study and reference strains, resulting in a product of $779 \mathrm{bp}$ (Fig. 1).

\section{RFLP analysis}

The digestion patterns obtained for the under study strains are shown in Fig.3 (a, b, and c). The most prevalent molecular type was VNI with $68.75 \%(n=55)$; secondly, the molecular type VGII with $15 \%(\mathrm{n}=12)$, followed by VNII with $11.25 \%(n=9)$, VGIII with $2.5 \%(n=2)$, and VNIII and VGI with $1.25 \%(\mathrm{n}=1)$, each one respectively. Table I shows the distribution of the genotypes of each of the complexes in relation to the patient's base disease and the Fig. 2 shows the geographical distribution of the genotypes.

\section{DISCUSSION}

The increase of opportunistic infections in patients with AIDS has been overwhelming, with a worldwide estimate of one million cases of cryptococcosis, with a mortality rate 
TABLE I.

DISTRIBUTION OF THE UNDERLYING DISEASES ASSOCIATED WITH THE C. NEOFORMANS/C. GATTII SPECIES COMPLEX

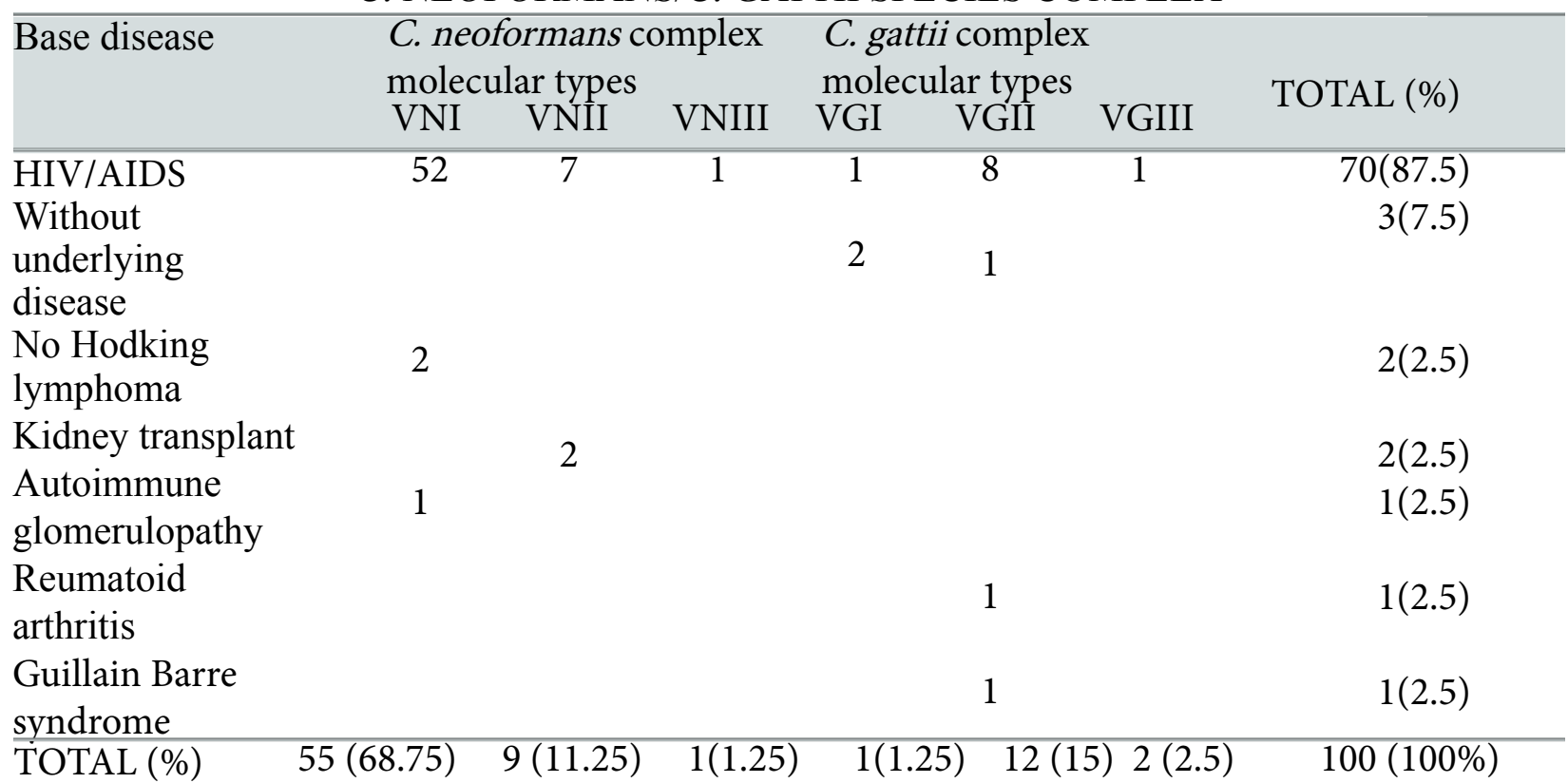

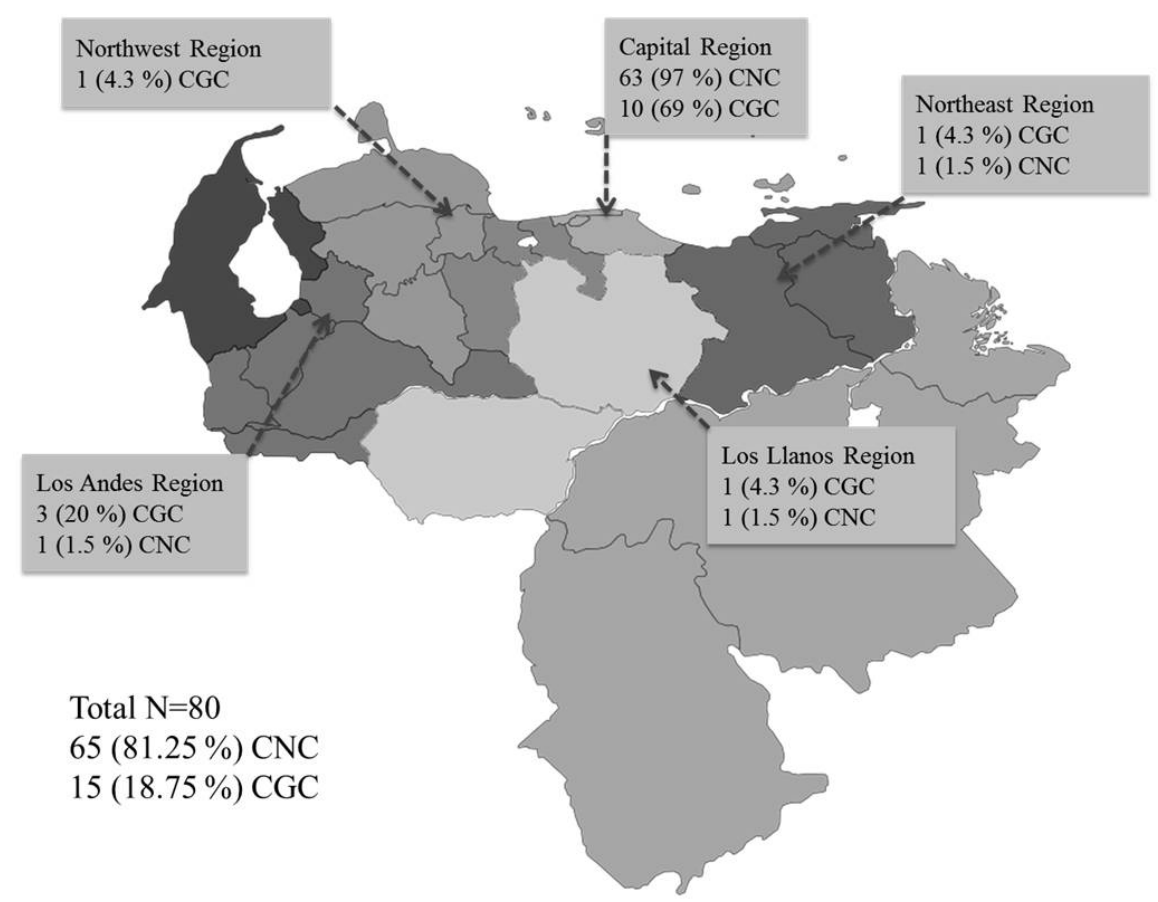

Fig.2. Distribution of the $C$. neoformans/C. gattii species complex by geographical regions in Venezuela 

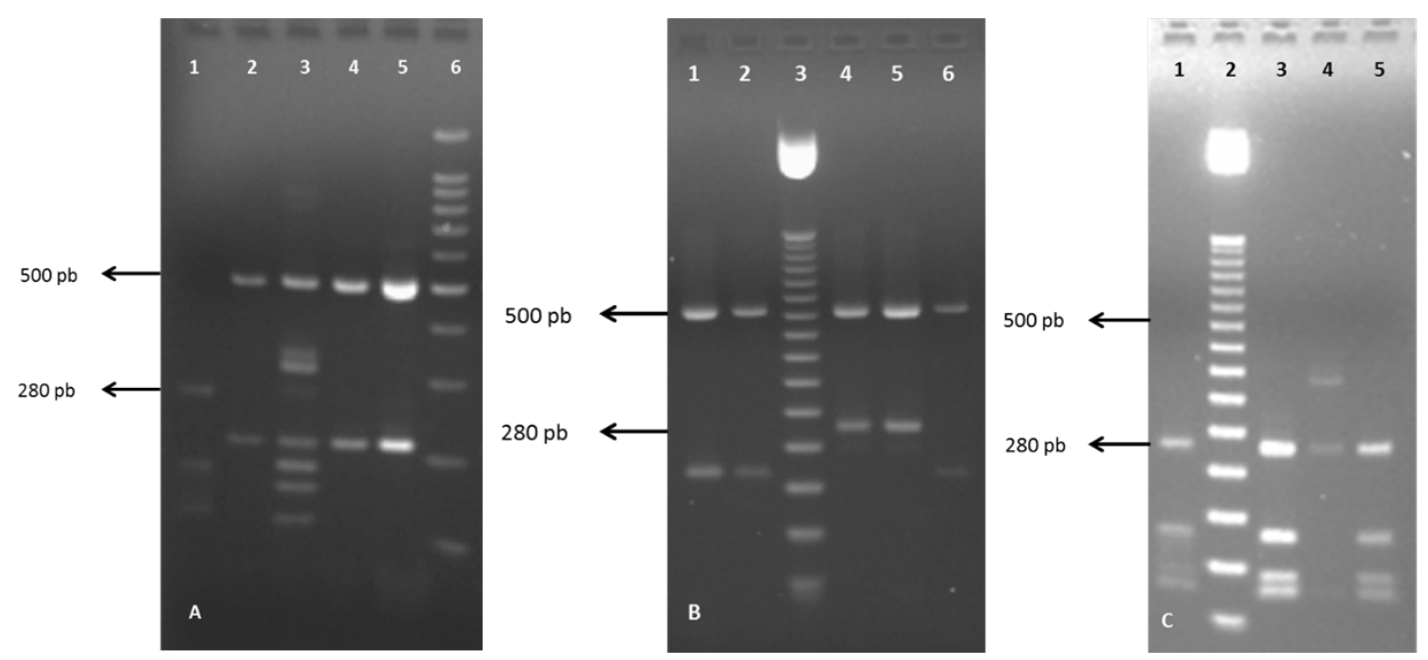

Fig.3. PCR-RFLP products by double digestion with Sau96I and HhaI enzymes of the clinical strains of this study. 3A. Column 1: VGII molecular type (strain3). Column 2: VNI molecular type (strain 4). Column3: VNIII molecular type (strain 5). Column 4: VNI molecular type (strain 6). Column 5: VNI molecular type (strain 7). Column 6: 100 bp molecular marker.

3B. Column 1: VNI molecular type (strain 25). Column 2: VNI molecular type (strain 26). Column 3: 50 bp molecular marker. Column 4: VNII molecular type (strain 27). Column 5: VNI molecular type (strain 28). Column 6: VNI molecular type (strain 29).

3C. Column 1: VGII molecular type (strain 80). Column 2: 50 bp molecular marker. Column 3: VGII molecular type (strain 81). Column 4: VGIII molecular type (strain 84). Column 5: VGII molecular type (strain 85).

close to $60 \%(625,000$ deaths per year) (1). $C$. neoformans/C. gattii species complex differ in their ecological, epidemiological and pathogenicity characteristics. The CNC has a universal geographical distribution and predominates in immunocompromised patients, especially with HIV/AIDS, whereas CGC, with a geographical distribution limited to tropical and subtropical areas, it prevails in immunocompetent as well as immunocompromised patients (2-6,24).

The molecular types of the Cryptococcus genus are the result of a complex process of adaptation, in which the genetic recombination and other virulence factors have played an important role, allowing its survival both in the environment and in the human being, showing great plasticity and microevolution capacity.
The information generated by molecular tests, related to clinical data, has revealed that the genotype responsible for infection can predict which immune response will be developed and the patient's death risk, associating them to a better or worst prognosis $(1,6,11)$.

Although numerous molecular techniques have been used for the $C$. neoformans/ $C$. gattii species complex typing, only PCR-FP, PCRRFLP and MLST have allowed the achievement of comparable results, the latter being considered the gold standard for the molecular characterization of the Cryptococcus genus. However, for cost effectiveness reasons, the PCR-FP and the PCR-RFLP have been used to a greater extent $(3,12,25)$. Particularly, the URA5 gene amplification by PCR-RFLP has permited to obtain specific patterns for each molecular 
type after the enzymatic digestion; by making the visual comparison of these patterns with those of the reference strains, an easy and quick identification of the molecular types is achieved $(3,7,25)$. Due to the advantages described above, and the availability of resources, the PCR-RFLP technique was used in this work.

Scarce national reports have information on the most common serotypes and molecular types circulating in the country (15-19). An Ibero-American study, which included some Venezuelan strains $(n=20)$, reported that the VNI molecular type was the most frequent in Venezuela $(75 \%)$, followed by VGI $(31.6 \%)$ and VNII (5\%) (26). It is important to note that the addition of the percentages obtained in this work, results in $111.6 \%$, and the absolute value of isolates number for each genotype was not included. In addition, the discussion describes the obtainment of VGIII type for Argentina, Colombia, Guatemala, Mexico and Venezuela, a result that differs with the observed one in the figure presented in this work.

On the other hand, in the review by Cogliati et al. (25), which refers to the same Venezuelan strains of the Ibero-American study of Meyer et al (26), the absolute values of the reported molecular types were: $70 \%(\mathrm{n}=14)$ for $\mathrm{VNI}$; $25 \%(\mathrm{n}=5)$ for VGI, and $5 \%(\mathrm{n}=1)$ for VNIII. These data do not agree with the percentages of the study of Meyer et al, nor with the reported VNIII molecular type. In the literature, the report of these data generates confusion about the prevalence of the different genotypes of the species complex of the Cryptococcus genus in Venezuela, causing an overestimation.

Table II shows the results obtained in this work comparing them with those of other national and international researchers (3,25-29). The most prevalent molecular type obtained in this study was VNI, with $68.75 \%$, result similar to that of other researchers $(3,16,25,26,29)$. This molecular type is the causal agent of cryptococcal disease in immunocompromised patients, particularly with HIV/AIDS (3,16,2729). Secondly, the VGII molecular type (15\%) was found, a different result than that found by Meyer et al in the Ibero-American study (26), where the second molecular type in Venezuela was VGI, but which is consistent with that reported for Latin America in the review by Cogliati et al (25) and other researchers $(3,29)$. We presume that this discrepancy with respect to what is reported for the VGI molecular type may be due to the fact that the Venezuelan isolates, included in the study by Meyer et al (26), come from that carried out by Calvo et al in 2000 (30); of the 20 strains used, 17 corresponded to $C$. neoformans var. neoformans and only three to $C$. neoformans var. gattii, which were isolated in the city of Maracaibo. However, this information is not specified in the above mentioned publication (26).

In the present work we characterized 15 strains of CGC from different regions of the country, so we infer that the previous result may be due to a particularity of this Venezuelan region; therefore, it is necessary to establish the CGC ecological niche and possible endemic areas in Venezuela, in order to answer this question. It is also important to highlight that the strains used in our work correspond to the period between 2004-2014 and do not correspond to those used by Meyer et al (26), nor those used by Perez et al (15).

There is increasing evidence of the association between the CGC molecular type and the host, but it has not yet been demonstrated (24). In this study, VGI and VGIII molecular types represented $1.25 \%$ and $2.5 \%$ respectively. It is important to note that VGI and VGII molecular types are more frequently involved in cases of cryptococcosis in immunocompetent patients, but cases have also been reported in immunocompromised patients. The VGIII and VGIV types are particularly involved in cases 
TABLA II

FREQUENCY OF THE MOLECULAR TYPES OBTAINED IN THIS STUDY, VERSUS OTHER FINDINGS

\begin{tabular}{|c|c|c|c|c|c|c|c|c|c|}
\hline \multirow[b]{2}{*}{ Country(Reference) } & \multirow[b]{2}{*}{$\mathrm{N}$} & \multirow[b]{2}{*}{ VNI } & \multicolumn{7}{|c|}{ Molecular types (\%) } \\
\hline & & & VNII & VNIII & VNIV & VGI & VGII & VGIII & VGIV \\
\hline Venezuela [TS] & 80 & 68.75 & 11.25 & 1.25 & & 1.25 & 15 & 2.5 & \\
\hline Colombia $^{1}(3)$ & 425 & 63.3 & 0.7 & & & 0.5 & 28 & 5.2 & 2.4 \\
\hline Brazil (28) & 81 & 93.8 & & & & & 6.2 & & \\
\hline $\operatorname{Brazil}^{1}(29)$ & 441 & 63.9 & 5 & 0.2 & 3.2 & 3.2 & 20.9 & 3.6 & \\
\hline Argentina (27) & 26 & 88.5 & 7.7 & & & 3.8 & & & \\
\hline Venezuela (26) & 20 & 70 & 5 & & & 25 & & & \\
\hline Europe (25) & 8,736 & 59.1 & & 18.5 & 18.3 & 3.4 & 0.3 & 0.1 & \\
\hline Africa $^{1}(25)$ & $19,647^{\star}$ & 68 & 11 & 2 & & 1 & 0.25 & & 5 \\
\hline $\operatorname{Asia}^{1}(25)$ & 19,651 & 81 & 0.8 & 2.6 & 0.3 & 13.2 & 1.7 & 0.1 & 0.3 \\
\hline Oceanía $^{1}(25)$ & 2,518 & 27 & 7 & 1 & 1 & 39 & 22 & 3 & \\
\hline $\begin{array}{l}\text { Center andSouth } \\
\text { America }^{1}(25)\end{array}$ & 10,548 & 71 & 2 & 0.4 & 1 & 4 & 17 & 4 & 1 \\
\hline $\begin{array}{l}\text { North America }{ }^{1 * *} \\
(25)\end{array}$ & 7,922 & 33 & 1 & 5 & 5 & 7 & 44.2 & 4 & 1 \\
\hline
\end{tabular}

[TS]: This study. ${ }^{1}$ Include environmental and clinical strains. ${ }^{\star}$ Plus $13 \%$ of $C$. neoformans var. Botswana (VNB). ${ }^{* *}$ Include Canada, USA and Mexico.

of this disease in immunocompromised patients $(3,16,24,25,27-29,31)$. It is possible to observe, in Table II, that the distribution and prevalence of CGC molecular types is more heterogeneous and the presence of VGI and VGII types in Venezuela represents an extremely important epidemiological finding.

In the third place, the VNII molecular type was found with $11.25 \%$ frequency, a result different from that reported for Latin America (25), however it coincides with that reported by Meyer et al (26). In this study, we did not find the presence of VNIV and VGIV molecular types.

In spite of the presence of represented isolates of $C$. neoformans/ $C$. gattii species complex from different regions of Venezuela, this does not yet reflect the epidemiology of this disease in our country. The RRNIH is the national reference center for the diagnosis of infectious diseases, and it receives all those isolates from hospitals that do not have the required methodology for the phenotypic differentiation of these complexes. However, this does not constitute a representation of what circulates in the country. This implies an underestimation of the actual disease prevalence, since the Institute performs only passive surveillance.

To learn about the real prevalence of cryptococcal disease in Venezuela, it is necessary to establish a national epidemiological surveillance program, and consider it a notifiable disease to the Ministry of Health, since it is a problem of public health in population with risk factors.

Currently, $C$. neoformans and $C$. gattii form a complex of seven species. In 2015, Hagen et al. (31), through MLST studies, 
established the presence of nine clades, which correlated with the eight molecular types characterized by PCR-FP and PCR-RFLP, where $C$. neoformans corresponds to VNI and VNII types, $C$. deneoformans to VNIV type, $C$. gattii to VGI type, C. bacillisporust o VGIII type, $C$. deuterogattii to VGII type, $C$. tetragattii to VGIV type, and finally $C$. decagattii to VGIV and VGIIIc types. These advances have generated discussions about the widespread use of the described new species, according to the new nomenclature system versus the use of the species complex $(32,33)$. However, as explained by Hagen et al. (33), there are differences in terms of geographical distribution, ecological niche, susceptibility to antifungal and clinical response, demonstrated for some $C$. neoformans/ $C$. gattii species complex.

According to these findings, and the results obtained in this study, we can affirm that in Venezuela have been isolated: $C$. neoformans $(80 \%)$, C. deuterogattii (15\%), C. bacillisporus (2.5\%), C. gattii $(1.25 \%)$ and $C$. neoformans VNIII $(1.25 \%)$, which corresponds to the interspecies hybrid between $C$. neoformans and $C$. deneoformans, information contributing to the understanding of the cryptococcal disease epidemiology in our country.

Genetic variability gives to the Cryptococcus genus great adaptability, both in the host and in the environment, and this translates into changes in the paradigms about the global distribution of these molecular types. So, epidemiological surveillance studies are necessary, which will allow clinicians to know about the molecular types that circulate in each region of Venezuela. This way will improve its responsiveness, focused on the virulence of the strain involved and the immune response of the host.

Finally, this work represents the first molecular study carried out with a significant number of strains of the $C$. neoformans/C. gattii species complex in Venezuela. It has allowed us to know the distribution and frequency of these molecular types at the clinical field, leaving an opened door for studies with environmental isolates, using other molecular techniques that complement the understanding of its epidemiology in terms of the reservoir, source of infection, and the relationship between the molecular type, the clinical presentation of the disease, and antifungal susceptibility of the isolates. All of this information should help in the pursuit of improving the clinical management of patients with cryptococcosis, and preventing the development of the disease in populations at higher risk.

\section{ACKNOWLEDGMENTS}

We thank to doctors Patricia Escandon and Elizabeth Castañeda, from the National Institute of Health of Colombia, for providing the reference strains using in this study. To the technical and administrative personnel of the Mycology Department, and to the Diagnostic and Epidemiological Surveillance Management of the Rafael Rangel National Institute of Hygiene, for their collaboration in this work.

\section{REFERENCES}

1. Kronstad JW, Attarian R, Cadieux B, Choi J, D' Souza CA, Griffiths EJ, Geddes JM, Hu G, Jung WH, Kretschmer M, Saikia S, Wang J. Expanding fungal pathogenesis: Cryptococcus breaks out of the opportunistic box. Nat Rev Microbiol 2011; 9:193-203.

2. Negroni R. Cryptococcosis. Clin Dermatol 2012; 30:599-609.

3. Escandón P, Sánchez A, Martínez M, Meyer W, Castañeda E. Genetic diversity of clinical and environmental isolates of the Cryptococcus neoformans species complex in Colombia. FEMS Yeast Res 2006; 6:625635.

Vol. 59(1): 28 - 40, 2018 
4. May RC, Stone N, Wiesner D L, Bicanic T, Nielsen $K$. Cryptococcus: from environmental saprophyte to global pathogen. Nat Rev Microbiol 2016; 14:106117.

5. Perfect J, Bicanic T. Cryptococcosis diagnosis and treatment: What do we know now. Fungal Genet Biol 2015; 78:49-54.

6. Rivera V, Gaviria M, Muñoz-Cadavid C, Cano L, Naranjo T. Validation and clinical application of a molecular method for the identification of Cryptococcus neoformans/ Cryptococcus gattii complex DNA in human clinical specimens. Braz J Infect Dis 2015; 19:563-570.

7. Sidrim JJ, Costa AK, Cordeiro RA, Brilhante RS, Moura FE, CasteloBranco DS, Neto MP, Rocha MF. Molecular methods for the diagnosis and characterization of Cryptococcus: a review. Can J Microbiol 2010; 56:445-458.

8. Lockhart SR, Iqbal N, Bolden CB, DeBess EE, Marsden-Haug N, Worhle R, Thakur R, Harris JR. Cryptococcus gattii PNW Public Health Working Group. Epidemiologic cutoff values for triazole drugs in Cryptococcus gattii: correlation of molecular type and in vitro susceptibility. Diag Microbiol Infect Dis 2012; 73:144148.

9. Posteraro B, Vella A, Cogliati M, De Carolis E, Florio A, Posteraro P, Sanguinetti M, Tortorano AM. Matrixassisted laser desorption ionization-time of flight mass spectrometry-based method for discrimination between molecular types of Cryptococcus neoformans and Cryptococcus gattii. J Clin Microbiol 2012; 50: 2472-2476.

10. Ulrich K, Ngamskulrungroj P, Meyer W. M13 PCR fingerprinting detects genetic instability of Cryptococcus gattii after passage through a rat model of infection.
Austral Mycol 2009; 28: 20-23.

11. Wiesner D, Moskalenko O, Corcoran JM, McDonald T, Rolfes MA, Meya DB, Kajumbula H, Kambugu A, Bohjanen PR, Knight JF, Boulware DR, Nielsen K. Cryptococcal genotype influences immunologic response and human clinical outcome after meningitis. MBio [revista electrónica]. 2012;3:e00196-12. [consultado 01/09/2016]: Disponible en: http://mbio. asm.org/content/3/5/e00196-12.short.

12. Meyer W, Aanensen D, Boekhout $T$. Consensus multi-locus sequence typing scheme for Cryptococcus neoformans and Cryptococcus gattii. Med Mycol 2009; 47:561-570.

13. Byrnes EJ III, Wenjun L, Ren P, Lewit Y, Voelz K, Fraser J, Dietrich FS, May RC, Chatuverdi S, Chatuverdi V, Heitman J. A diverse population of Cryptococcus gattii molecular type VGIII in Southern Californian HIV/AIDS patients. PLoS Pathog [revista electrónica]. 2011; 7:e1002205. [consultado 15/08/2016]: Disponible en: http://journals. plos.org/plospathogens/article? $\mathrm{id}=10.1371$ / journal.ppat.1002205.

14. Hasimoto e Souza LK, Rodrigues Costa C, Lisboa Fernandes OF, Yano Abrão F, Silva TC, Martins Treméa C, Rodrigues Silva MR. Clinical and microbiological features of cryptococcal meningitis. Rev Soc Bras Med Trop 2013; 46:343-347.

15. Pérez C, Dolande M, Moya M, Roselló A, Hartung de Capriles $C$. Landaeta ME, Mata-Essayag S. Cryptococcus neoformans, Cryptococcus gattii: serotypes in Venezuela. Mycopathologia 2008; 166:149-153.

16. Calvo B, Colombo A, Fischman O, Thompson S, Lazera M, Telles F, Fukushima K, Nishimura $K$, Tanaka R, Myiajy M, Moretti-Branchini ML. Antifungal susceptibilities varieties and 
electrophoretic karyotypes of clinical isolates of Cryptococcus neoformans from Brazil, Chile and Venezuela. J Clin Microbiol 2001; 39: 2348-2350.

17. Pérez $C$, Hernández $Y$, Guzmán $M$, Arias F, Nweihed L, Landaeta M, Borges R, Madera C, Roselló A, Colella MT, Hartung C, Mata-Essayag S. Estudio clínico-epidemiológico de la criptococosis en Venezuela, años 1994-2003. Kasmera 2009; 37: 140-147.

18. Santiago A, Hernández E, Aceituno H, Pabón R, Ferreira T. Prévalence des mycoses chez les patients du SIDA á l' Hopital Universitarie de Caracas (Venezuela). J Mycol Méd 1997; 7:51-52.

19. Villanueva E, Mendoza M, Torres E, Albornoz MB. Serotipificación de 27 cepas de Cryptococcus aisladas en Venezuela. Acta Cient Venez 1989; 40:151-154.

20. Huppert M, Harper G, Sun S, Delanerolle V. Rapid methods for identification of yeast. J Clin Microbiol 1975; 2:21-34.

21. Moore J, Johnson M, McClary S. Disk inoculum-solid medium method to test carbon and nitrogen assimiliation by yeast isolates. Appl Environ Microbiol 1988; 54:3185-3186.

22. Castellani A. Viability of some pathogenic fungi in distilled water. J Trop Med Hyg 1939; 42: 225-226.

23. Kwon-Chung KJ, Polachek I, Bennett JE. Improved diagnostic medium for separation of Cryptococcus neoformans var. neoformans (serotypes A and B) and Cryptococcus neoformans var. gattii (serotypes B and C). J Clin Microbiol 1982: 15:535-537.

24. Chen SC, Meyer W, Sorrell TC. Cryptococcus gattii infections. Clin Microbiol Rev 2014;27:980-1024

25. Cogliati M. Global molecular epidemiology of Cryptococcus neoformans and
Cryptococcus gattii: an atlas of the molecular types. Scientifica [revista electrónica]. 2013; 2013: 675213. [consultado 25/08/2016]: Disponible en: http://www.hindawi.com/ journals/scientifica/2013/675213/abs/.

26. Meyer W, Castañeda A, Jackson S, Huynh $M$, Castañeda $E$ and the Ibero American Cryptococcal Study Group. Molecular typing of Ibero American Cryptococcus neoformans. Emerg Infect Dis 2003; 9:189195.

27. Cattana M E, Tracogna MF, Fernández M, Carol MC, Sosa M, Giusiano G. Genotipificación de aislamientos clínicos del complejo Cryptococcus neoformans/ Cryptococcus gattii obtenidos en el Hospital «Dr. Julio C. Perrando», de la ciudad de Resistencia (Chaco, Argentina). Rev Argent Microbiol 2013; 45:89-92.

28. Mora DJ, Pedroza AL, Rodrigues V, Leite Maffei CM, Trilles L, Dos Santos Lazera M, Silva Vergara ML. Genotype and mating type distribution within clinical Cryptococcus neoformans and Cryptococcus gattii isolates from patients with cryptococcal meningitis in Uberaba, Minas Gerais, Brazil. Med Mycol 2010; 48: 561-569.

29. Trilles L, Dos Santos M, Wanke B, Vasconcelos R, Goncalves C, Martins M, Penarrieta B, Meyer W. Regional patterns of the molecular types of Cryptococcus neoformans and Cryptococcus gattii in Brazil. Mem Inst Oswaldo Cruz 2008; 103:455-462.

30. Calvo B, Colombo A, Fishman O, Santiago A, Nunes F, Branchini ML. Evaluación de la susceptibilidad antifúngica y cariotipo de Cryptococcus neoformans, aislados de muestras clínicas en Venezuela. Kasmera 2000; 28: 115-131

31. Hagen F, Khayhan K, Theelen B, Kolecka A, Polacheck I, Sionov E, Falk R, Parnmen

Vol. 59(1): 28 - 40, 2018 
S, Lumbsch HT, Boekhout T. Recognition of seven species in the Cryptococcus gattiil Cryptococcus neoformans species complex. Fungal Genet Bio 2015; 78:16-48.

32. Kwon-Chung KJ, Bennett JE, Wickes BL, Meyer W Cuomo CA, Wollenburg KR.The case for adopting the "species complex" nomenclature for the etiologic agents of cryptococcosis. mSphere 2017;2: e00357-
16. doi:10.1128/mSphere.00357-16.

33. Hagen F, Thorsten Lumbsch $H$, ArsicArsenijevic V, Badali $\mathrm{H}$, Bertout S, Billmyre B. Importance of resolving fungal nomenclature: the case of multiple pathogenic species in the Cryptococcus genus. mSphere 2017;2:e00238-17. doi:10.1128/mSphere.00238-17 